\title{
A first report on a bloom of the marine prymnesiophycean, Phaeocystis globosa from the Arabian Sea
}

\author{
M. MADHUPRATAP ${ }^{a *}$, Surekha SAWANT ${ }^{\text {b }}$, Mangesh GAUNS ${ }^{\text {a }}$ \\ a National Institute of Oceanography, Dona Paula, Goa, 403 004, India \\ ${ }^{\mathrm{b}}$ Institute of Wood Science and Technology (IWST), P.O. Malleshwaram, Bangalore, 560003 , India
}

Received 20 July 1998; revised 30 June 1999; accepted 20 August 1999

\begin{abstract}
A thick bloom of the marine prymnesiophycean, Phaeocystis globosa was observed in the central Arabian Sea during the summer monsoon period (July-August, 1996). The cells were mostly in colonial form, embedded in gelatinous matrices. The cell diameter was approximately $7 \mu \mathrm{m}$ and showed a distinct double feature form. The intensity of the bloom was as high as $3750 \times 10^{6}$ cells $\mathrm{m}^{-2}$ and the carbon content ranged between 33 and $550 \mu \mathrm{g} \mathrm{L}^{-1}$. Almost $90 \%$ of the phytoplankton population was composed of $P$. globosa in the bloom area. Other common forms were chain-forming diatoms like Rhizosolenia spp., Nitzschia spp. and Chaetoceros spp. The photosynthetic pigment chlorophyll $a$, however did not show any concomitant rise with the bloom intensity probably because the bloom was sampled during a senescent phase. The carbon chlorophyll ratio varied between 112 and 810. This is the first report on the occurrence of Phaeocystis from the Arabian Sea. It seems pertinent to ask whether this is a result of the genus being introduced and adapted to new environments due to human influence and whether it will influence food chains in the future. (C) 2000 Ifremer/CNRS/IRD/Éditions scientifiques et médicales Elsevier SAS
\end{abstract}

\section{Prymnesiophyceae / Phaeocystis / bloom / Arabian Sea}

Résumé - Premières observations de la prymnésiophycée marine Phaeocystis globosa en mer d'Arabie. Une floraison importante de la prymnésiophycée marine Phaeocystis globosa est observée au centre de la mer d'Arabie pendant la mousson d'été, en juillet-août 1996. Les cellules forment en général une colonie incluse dans une gangue gélatineuse. D'un diamétre d'environ $7 \mu \mathrm{m}$, les cellules ont une forme caractéristique double. L'intensité de la floraison est de $3750 \times 10^{6}$ cellules par $\mathrm{m}^{2}$, avec une teneur en carbone comprise entre 33 et $550 \mu \mathrm{g} \mathrm{L}^{-1}$. La population phytoplanctonique est composée, pour près de $90 \%$ de $P$. globosa; les autres formes communes sont des chaînes de diatomées telles que Rhizosolenia spp., Nitzschia spp. et Chaetoceros spp. La teneur en chlorophylle $a$ ne présente cependant pas d'augmentation concomitante à la poussée de la floraison, probablement parce que celle-ci a été échantillonnée dans une phase de sénéscence. Le rapport chlorophylle/carbone varie entre 112 et 810 . Cette première observation de Phaeocystis en mer d'Arabie pose des questions: provient-elle d'un genre introduit par l'homme et qui se serait adapté à de nouveaux environnements ? Quel sera son effet éventuel sur les chaînes alimentaires? (C) 2000 Ifremer/CNRS/IRD/Éditions scientifiques et médicales Elsevier SAS

prymnesiophycée / Phaeocystis / floraison / mer d'Arabie

\footnotetext{
* Correspondence and reprints: madhu@csnio.ren.nic.in
} 


\section{INTRODUCTION}

The colony forming prymnesiophyte, Phaeocystis, is an important component of phytoplankton community in marine ecosystems. It occurs worldwide, both in temperate [10] and cold polar waters [12, 22, 40] with occasional references to warmer seas [1]. Phaeocystis is one of the few marine phytoplankton species often found in gelatinous colonial aggregation of non-motile cells, containing hundreds to thousands of cells in colonies, which may exceed $10 \mathrm{~mm}$ in diameter [13, 18]. Large blooms of colonial Phaeocystis have been documented for over 100 years [14] from the marine environment.

While some controversy exists on the taxonomical identity of various Phaeocystis species [25, 37], the most important are $P$. pouchetii, dominant in the northern boreal and polar waters, $P$. antarctica, found in the Southern Ocean and P. globosa, a warm water counterpart, found in temperate and at times in tropical waters. The blooming of this prymnesiophyte is found to be associated with the nutrient enrichment often as a result of anthropogenic inputs into the water column [38] and therefore, their occurrence is most common in coastal waters. However, it rarely blooms in the open ocean as well [31].

The Arabian Sea is part of the Indian Ocean and is a warm tropical basin. It is land-locked on three sides, bordered by the African continent to the west, the Indian subcontinent to the east and Asia to the north. To the west, the Red Sea and Arabian Gulf open into it. The main characteristics of the area are general high salinity (ca. 36) and seasonal reversals in circulation generated by the monsoons. During southwest (summer: June to October) monsoon, circulation is clockwise and it reverses during northeast monsoon (winter: November to May). These seasonal changes profoundly influence the physics, chemistry and biology of the area $[20,41]$.

Phytoplankton in the Arabian Sea is generally dominated by diatoms [30] and their blooms are a common feature [27]. These reports are mainly on diatoms like Fragilaria oceanica, Coscinodiscus spp., Chaetoceros spp., Leptocylindrus spp., Navicula spp., Nitzschia spp., Pleurosigma spp., Rhizosolenia spp., and Skeletonema spp. Blooms of the dinoflagellate Noctiluca and the blue green alga Trichodesmium erytheraeum are also regular [6]. However, interestingly, there is no record so far on the presence/domi- nance of Phaeocystis in the Arabian Sea. The only record of this genus from this region is from the coastal waters of the Arabian Gulf [1].

Our observations on Phaeocystis globosa, apart from being the first report from the Arabian Sea, is all the more interesting since the bloom occurred in the open ocean waters.

\section{MATERIAL AND METHODS}

The Phaeocystis bloom was observed during the 115th cruise of O.R.V. Sagar Kanya, during the summer monsoon period (July-August, 1996). The stations were located at $2^{\circ}$ intervals along the $64^{\circ} \mathrm{E}$ between $13-19^{\circ} \mathrm{N}$ in the open waters. At each station, water samples were collected from eight depths $(0,10,20,40,60,80,100$ and $120 \mathrm{~m})$ using GO-Flo samplers fitted on a CTD rosette, attached to a plastic-coated winch wire. $250 \mathrm{~mL}$ of the water samples were immediately fixed in $1 \%$ Lugol's Iodine and preserved by adding a few drops of buffered formaldehyde solution. The preserved samples were stored at a low temperature until enumeration, i.e. within a period of one month.

Identification of Phaeocystis to species level as $P$. globosa was independently confirmed from samples sent to the Alfred-Wegener Institute, Germany. The algal cells were concentrated following settling and siphoning procedure (through $20 \mu \mathrm{m}$ mesh) to obtain a $20 \mathrm{~mL}$ concentrate. $1 \mathrm{~mL}$ of this concentrate was then mounted on a Sedgewick-Rafter counting chamber for qualitative and quantitative analysis of phytoplankton. The analysis was done in triplicates under a Leica Inverted microscope $(100 \times$ and $400 \times$ magnifications). Size analysis of cells and colonies was done using an occular-micrometer. Phaeocystis cell carbon was a value of estimated from cell numbers using $8.6 \mathrm{pg} \mathrm{cell}^{-1}$ [11]. Chlorophyll $a$ was determined by filtering one litre of water sample through $\mathrm{GF} / \mathrm{F}$ Whatman filter. The pigments were extracted using $10 \mathrm{~mL}$ of $90 \%$ acetone. The fluorescence was then measured in a Turner Design Fluorometer before and after acidification with two drops of $1.2 \mathrm{~N} \mathrm{HCl}$ to the pigment extracts [35].

Particulate organic carbon (POC) was measured by filtering one litre of water sample onto a precom- 
busted $25 \mathrm{~mm} \mathrm{GF} / \mathrm{F}$ filter (nominal pore size $0.7 \mu \mathrm{m}$ ). These filters were wrapped in precombusted aluminium foil and stored frozen $\left(-20^{\circ} \mathrm{C}\right)$ before analysis [35]. Later, these filters were dried overnight at $60{ }^{\circ} \mathrm{C}$. The dried filters were exposed to fuming $\mathrm{HCl}$ to remove inorganic carbonate. The filters dried again at $60^{\circ} \mathrm{C}$ were analysed for POC on a Perkin Elmer $2400 \mathrm{CHN}$ analyser. Standards and blanks were run before analysis of the samples. The POC carbon was used in estimating $\mathrm{C}: \mathrm{Chl} a$ ratios.

\section{RESULTS AND DISCUSSION}

The thick bloom of Phaeocystis globosa was observed continuously from $14^{\circ}-18^{\circ} \mathrm{N}$ (ca. 240 nautical miles) and was analysed at $15^{\circ}$ and $17^{\circ} \mathrm{N}$. The water was green in colour due to the bloom. The cells were mostly in the form of colonies and were embedded in a gelatinous matrix, secreted by the cells themselves. Although larger colonies lost their shape due to preservation, the smaller colonies showed distinct spherical shape and some of them were found attached to the larger colony matrix (figure 1). The cells were generally round and had typical double feature form with a size of approximately $7 \mu \mathrm{m}$ in diameter. The number of cells forming colonies had a very wide range. The minimum number of cells per colony was 9 whereas the largest colony had as many as 2700 cells per colony in the matrix. However, this is much less than the number of cells (10000 cells per colony) previously reported from the coastal waters of the North Sea [28].

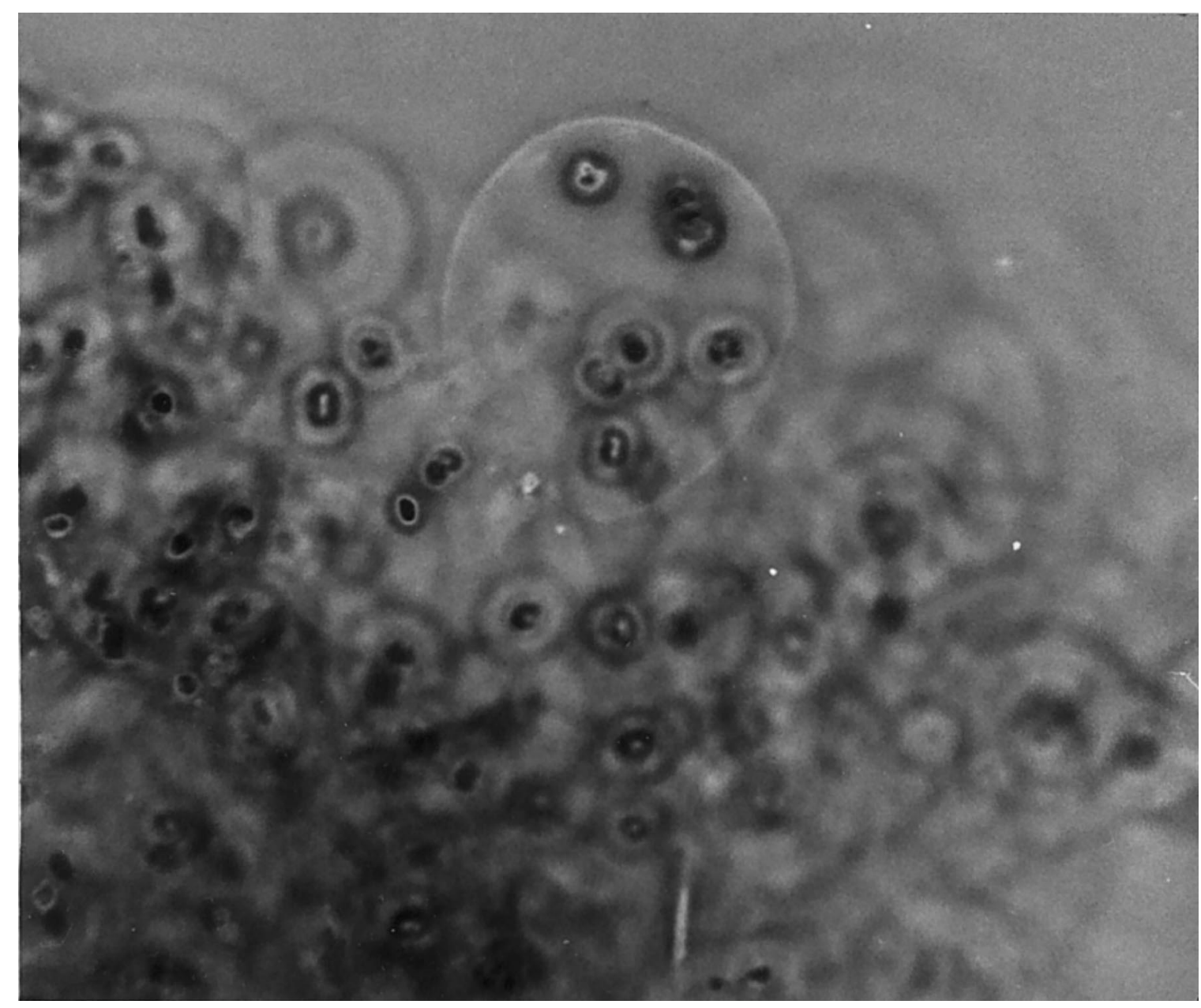

Figure 1. Photograph showing spherical Phaeocystis globosa colonies attached to larger colony. 


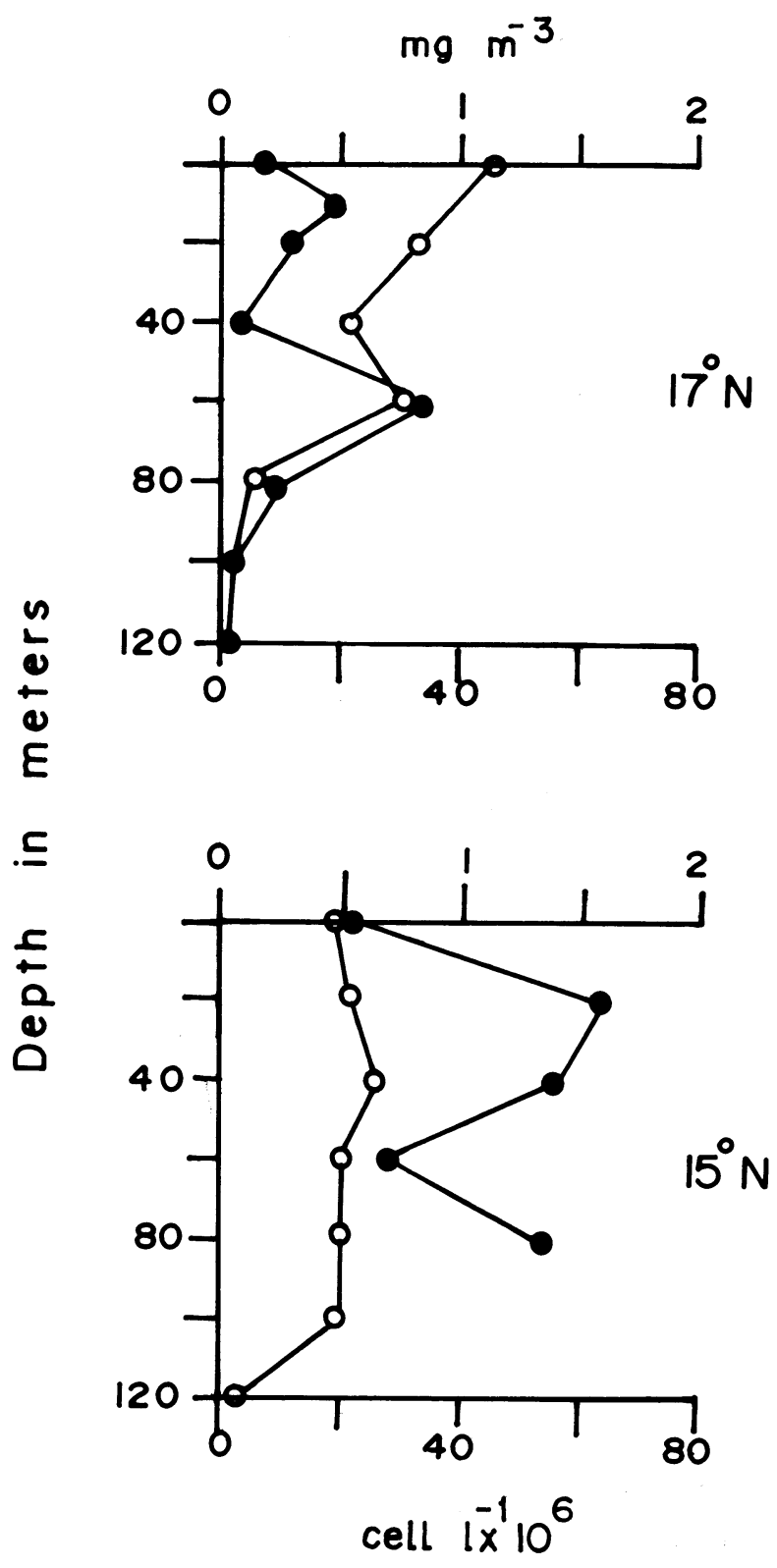

Figure 2. Vertical profiles of chlorophyll $a$ distribution $\left(\mathrm{mg} \mathrm{m}^{-3}\right.$, open circles) and Phaeocystis counts (cells $\mathrm{L}^{-1} \times 10^{6}$, closed circles) at $17^{\circ} \mathrm{N}$ and $15^{\circ} \mathrm{N}$ stations in the upper $120 \mathrm{~m}$.

At $15^{\circ} \mathrm{N}$ Phaeocystis cell counts ranged from 23 to $64 \times 10^{6} \mathrm{~L}^{-1}$ in the upper $80 \mathrm{~m}$ and this was between $2.2 \times 10^{6} \mathrm{~L}^{-1}$ and $35 \times 10^{6} \mathrm{~L}^{-1}$ at $17^{\circ} \mathrm{N}$ (figure 2 This is comparable to the cell numbers $\left(22 \times 10^{6}\right.$ cells $\mathrm{L}^{-1}$ ) observed along the Dutch coast of the North Sea [38]. The integrated cell counts were $3750 \times 10^{6}$ and $1410 \times 10^{6}$ cells $\mathrm{m}^{-2}$ respectively. Thus, the bloom density was higher at $15^{\circ} \mathrm{N}$ (almost threefold) as compared to $17^{\circ} \mathrm{N}$. The colonies were randomly distributed in the water column with maximum densities occurring between $20-80 \mathrm{~m}$ depth. The population of $P$. globosa below $80 \mathrm{~m}$ depth was almost negligible. Around 99 and $86 \%$ of the total phytoplankton biomass was Phaeocystis at $15^{\circ} \mathrm{N}$ and $17^{\circ} \mathrm{N}$ respectively. In terms of carbon this was $32-297$ and $198-550 \mu \mathrm{g} \mathrm{L}^{-1}$ at $15^{\circ} \mathrm{N}$ and $17^{\circ}$ N. Abundances of other phytoplankton however showed a reverse trend within these latitudes, cell counts were $0.7 \times 10^{6}$ cells $\mathrm{m}^{-2}$ at $17^{\circ} \mathrm{N}$ and down to $0.5 \times 10^{6}$ cells $\mathrm{m}^{-2}$ at $15^{\circ} \mathrm{N}$ (table I). However, these were higher compared to a station sampled in the south implicating availability of higher nutrients supply at northern locations.

Other phytoplankton mainly consisted of species like Nitzschia longissima, $N$. bilobata, $N$. directa, Rhizosolenia hebetata, $R$. stolterfothii, $R$. styliformis, $R$. cylindrus, $R$. alata, $R$. imbricata, $R$. fragillima, Chaetoceros didymus, C. peruvianus, C. borealis, C. indicus, Coscinodiscus sp., Navicula sp., Melosira sulcata, Cyclotella sp., Thallassiothrix frauenfeldii, Thalassiosira sp., Ditylum sp., Pleurosigma sp., Guinardia sp., Synedra robusta, Pyxidicula minuta, Bacteriastrum hyalinum, Actinoptychus sp., Climacodium frauenfeldianum, Climacosphenia elongata, Planktoniella sol, Ceratium furca, C. gibberum and Gymnodium lunula. The most abundant forms among these were chain forming diatoms Rhizosolenia stolterfothii, $R$. styliformis, Nitzschia spp. and Chaetoceros spp.

Table I. Counts of phytoplankton (cells $\mathrm{L}^{-1}$ ) other than that of Phaeocystis at stations along $64^{\circ} \mathrm{E}$ longitude

\begin{tabular}{lllll}
\hline Depth (m) & $13^{\circ} \mathrm{N}$ & $15^{\circ} \mathrm{N}$ & $17^{\circ} \mathrm{N}$ & $19^{\circ} \mathrm{N}$ \\
\hline 0 & 600 & 3300 & 12200 & 3900 \\
10 & 1400 & $\mathbf{-}^{\mathrm{a}}$ & 10700 & 3000 \\
20 & 1600 & 5100 & 11800 & 2600 \\
40 & 1100 & 6600 & 10100 & 5400 \\
60 & 1100 & 3500 & 12600 & 1700 \\
80 & 400 & 4900 & 2000 & 100 \\
100 & 300 & 1900 & 100 & - \\
120 & 500 & 100 & 100 & - \\
Integr. Counts & 104000 & 474000 & 717000 & 231500 \\
\hline
\end{tabular}

a -, no data. 


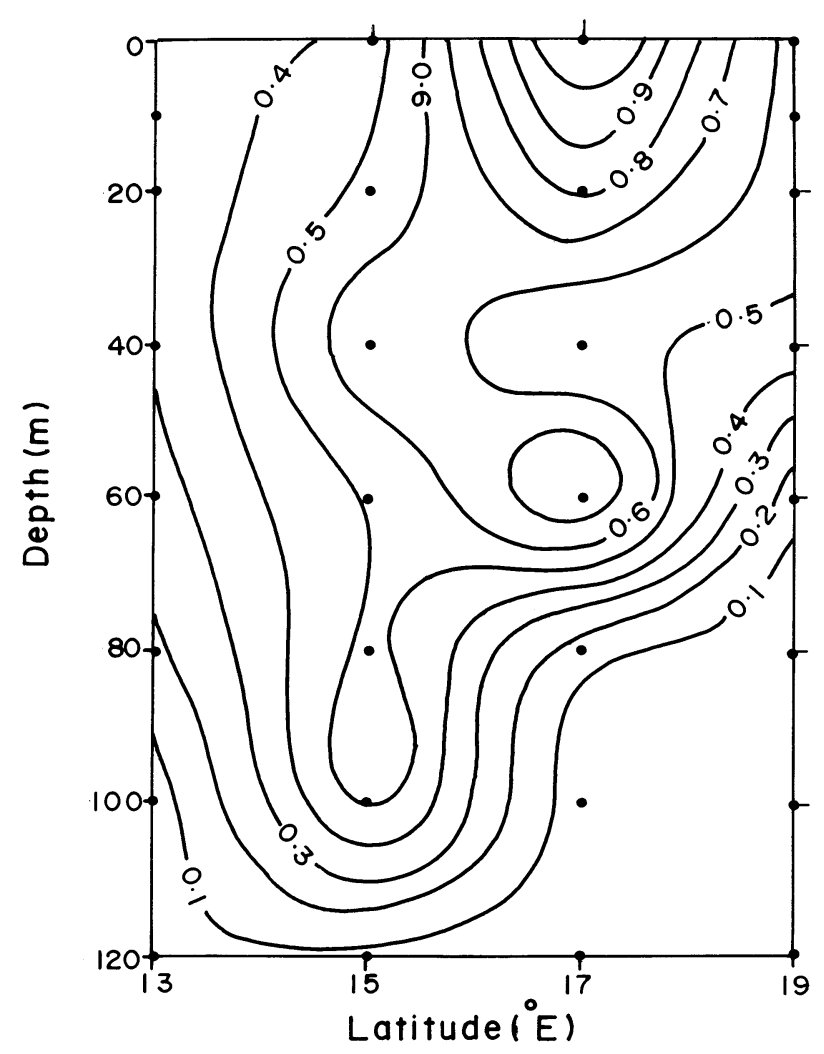

Figure 3. Latitudinal Chlorophyll $a$ profile along $64^{\circ} \mathrm{E}$.

In the course of this study chlorophyll $a$ was generally moderate at all stations (figure 3) although this pigment was expected to show a concomitant increase with the bloom. The chlorophyll $a$ values in the upper $120 \mathrm{~m}$ of the water column ranged from 0.07 to 0.65 $\mathrm{mg} \mathrm{m} \mathrm{m}^{-3}$ at $15^{\circ} \mathrm{N}$ and from 0.02 to $1.10 \mathrm{mg} \mathrm{m}^{-3}$ at $17^{\circ} \mathrm{N}$. The column values at the respective stations were 59.4 and $57.6 \mathrm{mg} \mathrm{m}^{-2}$. Chlorophyll $a$ values as high as $50 \mathrm{mg} \mathrm{m}^{-3}$ associated with Phaeocystis blooms has been reported [23]. Nitrate was at undetectable levels in the upper water column (figure $4)$, whereas phosphate was at moderate levels ( 0.02 to $0.57 \mu \mathrm{M} \mathrm{L}^{-1}$ )

P. globosa cells forms colonies embedded in a mucus matrix made up of polysaccharides. This mucus envelope, besides from mediating the exchange between the external medium and the colonial cells, also forms an energy substrate which could be used for pursuing growth in the absence of light [21]. Prymnesiophyte blooms are often known to co-occur with the chain forming diatoms [7], as we observed. The presence of a few dinoflagellate Noctiluca sp. indicated that the bloom was in a senescent phase (Christian Hamm, pers. comm.).

One interesting feature was the low chlorophyll $a$ and high biomass condition during the bloom which ranged from 112 to 810 . This is typical of late bloom conditions when nitrogen becomes limiting, as in our study. In a nitrogen-limited medium, it has been shown that the C:Chl $a$ ratio can become quite high (up to 620 [39]) so that the absolute biomass can still be high while chlorophyll $a$ concentration is low. Growth of Phaeocystis is limited either by nitrogen [21] or phosphate $[4,17,36,38]$.

During the summer monsoon extensive upwelling brings up nutrients along the Somalia and Arabian coast through Ekman pumping [33]. In the open ocean, upwelling in northern Arabian Sea occurs north of the Findlater Jet which approximately passes along $15^{\circ} \mathrm{N}$ at $64^{\circ} \mathrm{E}$ [24]. This happens as a result of positive wind stress curl north of the jet. The mixed layer depth shoaled from $100 \mathrm{~m}$ at $13^{\circ} \mathrm{N}$ to $45 \mathrm{~m}$ at the bloom area (S.P. Kumar, pers. comm.). This open ocean upwelling pumps up nutrients to the upper layers as a result of Ekman suction and has been already demonstrated ([3], see also figure 4). As mentioned earlier, we probably sampled the bloom at a late phase. Thus, the bloom occurred as a result of increase in nutrients, but not because of eutrophication or anthropogenic inputs as commonly observed in European waters [cf. 5, 38].

Studies have shown that Phaeocystis is ingested by some zooplankton species [8] but grazing is not very important in controlling the abundances [15]. Usually the isolated cells and the small colonies are used as food by grazers. Lack of efficient grazing on large Phaeocystis colonies leads to production of thick foam apart from export to the deep. The aggregates rapidly sink out of the euphotic zone [40] thus contributing to the carbon cycle and particle flux. Transparent Exopolymer Particle concentrations were as high as $102 \mathrm{mg}$ equivalents of algenic acid per litre at $600 \mathrm{~m}$ depth in the bloom area [19]. Up to two metres' thickness of slimy foam, resembling egg whites, with a strong smell has been seen deposited on the beaches of Netherlands and Germany [23] causing a hindrance to the recreational activities. We do not yet know if such scenarios are a possibility on the beaches around the Arabian Sea in the future. A more worrying question is whether this newcomer 
will affect the food chains. Ephemeral and innocuous as it may seem, Phaeocystis bloom is known to increase in density over the years [5] and if it spreads to the coastal eutrophicated waters of India, it may affect the fisheries badly.

Phaeocystis sp. often forms massive blooms in temperate and polar regions and is an important contributor both to global primary productivity and flux of the volatile sulfur compounds from the ocean to the atmosphere. Phaeocystis blooms are also thought to have an impact on global climatic changes as it is one of the few phytoplankton genus known to produce dimethyl sulfide, DMS [2, 22]. Although this sulfur compound counteracts the greenhouse effects it may locally contribute to acid rain as the oxidised prod- ucts of DMS are a major source of marine aerosol particles to the atmosphere $[2,16,34]$.

\section{CONCLUSIONS}

Several questions should be considered. Documentation of phytoplankton species occurring in the Arabian Sea goes back to the 1930s (e.g. [26, 32]). Phaeocystis appears to be a new introduction to the Arabian Sea, as has been the case for some zooplankton species elsewhere, through ballast tanks (cf. [9]). We can expect blooms in coastal waters to lead to the formation of foams on the beaches or affect food chains and fisheries in the future. The Arabian Sea is

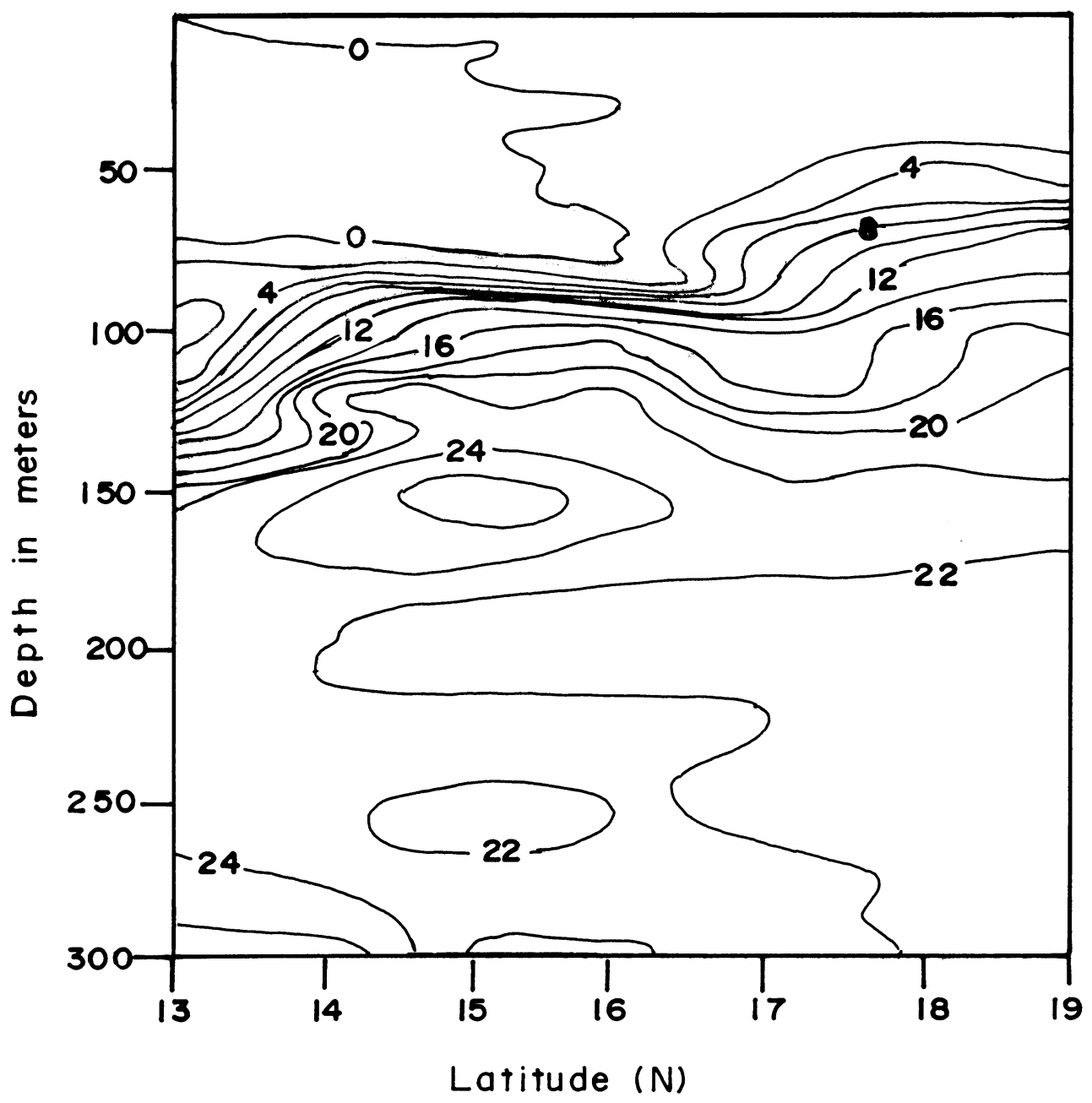

Figure 4. Latitudinal nitrate profile along $64^{\circ} \mathrm{E}$. 
apparently a source of greenhouse gases [29]; can such blooms change it to a sink through carbon fixation and rapid export of particles?

\section{Acknowledgements}

Our sincere thanks are due to Dr Christian Hamm and Prof. Victor Smetacek, Alfred-Wegener Institute, Germany, for identifying the species of Phaeocystis and information on P. globosa. Authors also thank Dr Lata Raghukumar of NIO, Goa for her help in this research. This study was conducted as part of the JGOFS (India) programme under a grant from the Department of Ocean Development, New Delhi. NIO contribution no: 2659.

\section{REFERENCES}

[1] Al-Hasan R.H., Ali A.M., Radwan S.S., Lipids and their constituent fatty acids of Phaeocystis sp. from the Arabian Gulf, Mar. Biol. 105 (1990) 9-14.

[2] Bates T.S., Cline J.D., The role of the ocean in a regional sulfur cycle, J. Geophy. Res. 90 (1985) 9168-9172.

[3] Bauer S.G., Hitchock L., Olson D.B., Influence of monsoonally forced Ekman dynamics upon surface layer depth and plankton biomass distribution in the Arabian Sea, Deep-Sea Res. 38 (1991) 531-553.

[4] Bennekom A.J., van Gieskes W.W.C., Tijssen S.B., Eutrophication of Dutch coastal waters, Proc. R. Soc. Lon. Ser. B 189 (1975) 359-374.

[5] Cadee G.C., Increase of Phaeocystis blooms in the westernmost inlet of the Wadden Sea, the Marsdiep, since 1973, in: Lancelot C., Billen G., Barth H. (Eds.), Water Poll. Res. Rep., Eutrophication and algal blooms in North Sea coastal zones, the Baltic and adjacent areas: prediction and assessment of preventive actions, Proc. workshop Comm. Eur. Comm. Environmental R \& D Programme, Brussels, 1989, pp. 105-111.

[6] Devassy V.P., Bhattathiri P.M.A., Qasim S.Z., Trichodesmium phenomenon, Indian J. Mar. Sci. 7 (1978) 168186.

[7] Eilertsen H.C., Schei B., Taasen J.P., Investigations on the plankton community of Balsfjorden, northern Norway: the phytoplankton 1976-78, Abundance, species composition and succession, Sarsia 66 (1981) 129-141.

[8] Estep K.W., Nejstgaard J.C., Skjoldal H.R., Rey F., Predation by copepods upon natural population of Phaeocystis pouchetii as a function of the physiological state of the prey, Mar. Ecol. Prog. Ser. 67 (1990) 235-248.

[9] Fleminger A., Hendrix-Kramer S., Recent introduction of an Asian estuarine copepod, Pseudodiaptomus marinus (Copepoda: Calanoida), into southern California embayments, Mar. Biol. 98 (1988) 535-541.
[10] Gaarder K.R., Coccolithineae, Silicoflagellateae, Pterospermataceae and other forms, in: Murray J., Hjort J. (Eds.), Rep. Scient. Results Michaelson's Atlantic deep-sea Expedition, 1910 2, 1954, pp. 1-28.

[11] Garrison D.L., Gowing M.M., Hughes M.P., Nano- and microplankton in the northern Arabian Sea during the Southwest Monsoon, Aug.-Sept. 1995, A US-JGOFS study, DeepSea Res. 45 (1998) 2269-2299.

[12] Gibson J.A.E., Garrick R.C., Burton H.R., McTaggart A.R., Dimethylsulfide and the alga Phaeocystis pouchetii in Antarctic coastal waters, Mar. Biol. 104 (1990) 339-346.

[13] Gieskes W.W.C., Kraay G.C., The phytoplankton spring bloom in Dutch coastal waters of the North Sea, Neth. J. Sea Res. 9 (1975) 166-196.

[14] Gran H.H., Das Plankton des Norwegischen Nordmeeres, Rep. Norweg. Fish. Mar-Inv. 2 (1902) 1-222.

[15] Hansen F.C., van Boekel W.H.M., Grazing pressure of the calanoid copepod Temora longicornis on a Phaeocystis dominated spring bloom in a Dutch tidal inlet, Mar. Ecol. Prog. Ser. 78 (1991) 123-129.

[16] Holligan P.M., Turner S.M., Liss P.S., Measurements of dimethyl sulphide in frontal regions, Cont. Shelf Res. 7 (1987) 213-224.

[17] Jones P.G.W., Haq J.M., The distribution of Phaeocystis in the eastern Irish Sea, J. Cons. Int. Explor. Mer. 28 (1963) $8-20$.

[18] Kayser H., Experimental-ecological investigations on Phaeocystis pouchetii (Haptophyceae): Cultivation and waste water test, Helgol. Meeresunters. 20 (1970) 195-212.

[19] Kumar M.D., Sarma V.V.S.S., Ramaiah N., Gauns M., de Sousa S.N., Biogeochemical significance of transparent exopolymer particles in the ocean, Geophys. Res. Lett. 25 (1998) $81-84$.

[20] Kray J., Babenerd B., Phytoplankton production atlas of the International Indian Ocean Expedition. Int. Oceanogr. Comm. Paris (1976) 70.

[21] Lancelot C., Mathot S., Biochemical fractionation of primary production by phytoplankton in Belgian coastal waters during short- and long-term incubations with ${ }^{14} \mathrm{C}$-bicarbonate. II, Phaeocystis pouchetii colonial population, Mar. Biol. 86 (1985) 227-232.

[22] Lancelot C., Billen G., Soumia A., Wiesse T., Colijin F., Veldhuis M.J.W., Davies A., Wassman P., Phaeocystis blooms and nutrient enrichment in the continental coastal zones of the North Sea, Ambio 16 (1987) 38-46.

[23] Lancelot C., Phaeocystis blooms in the continental coastal area of the channel and the North Sea, in: Lancelot C., Billen G., Barth H. (Eds.), Water Pollution Research Reports, Eutrophication and algal blooms in North Sea coastal zones, the Baltic and adjacent areas: prediction and assessment of preventive actions, Proc. workshop Comm. Eur. Comm. Environmental R \& D Programme, Brussels, 1989, pp. 27-54. 
[24] Madhupratap M., Prasanna Kumar S., Bhattathiri P.M.A., Dileep Kumar M., Raghukumar S., Nair K.K.C., Ramaiah $\mathrm{N}$., Mechanism of the biological response to winter cooling in the northeastern Arabian Sea, Nature 384 (1996) 549-552.

[25] Medlin L.K., Lange M., Barker G.L.A., Can molecular techniques change our ideas about the species concept?, in: Joint I. (Ed.), Molecular Ecology of Aquatic Microbes, Springer-Verlag, Heidelberg, 1995, pp. 133-152.

[26] Menon K.S., A preliminary account of Madras plankton, Rec. Indian Mus. 33 (1931) 489-516.

[27] Nair S.R.S., Devassy V.P., Madhupratap M., Blooms of phytoplankton along the west coast of India associated with nutrient enrichment and the response of zooplankton, Science of the Total Environment, Suppl. 1992, Elsevier (1992) 891828.

[28] Rousseau V., Mathot S., Lancelot C., Calculating carbon biomass of Phaeocystis sp. from microscopic observations, Mar. Biol. 107 (1990) 305-314.

[29] Sarma V.V.S.S., Dileep M., George M.D., The central and eastern Arabian Sea as a perennial source to atmospheric carbon dioxide, Tellus 50B (1998) 179-184.

[30] Sawant S., Madhupratap M., Seasonality and composition of phytoplankton in the Arabian Sea, Curr. Sci. 71 (1996) 869873.

[31] Smith W.O. Jr., Codispoti L.A., Nelson D.M., Manley T., Buskey E.J., Niebauer H.J., Cota G.F., Importance of Phaeocystis blooms in the high-latitude ocean carbon cycle, Nature 352 (1991) 514-516.

[32] Subrahmanyam R., Phytoplankton organisms of the west coast of India, J. Indian Bot. Soc. 37 (1958) 435-441.
[33] Swallow J.C., Some aspects of the physical oceanography of the Indian Ocean, Deep-Sea Res. 31 (1984) 639-650.

[34] Turner S.M., Liss P.S., Measurements of various sulphur gases in a coastal marine environment, J. Atmos. Chem. 2 (1985) 223-232.

[35] UNESCO, Protocols for the Joint Global Ocean Flux Study (JGOFS) Core Measurements, Sci. Comm. Oceanic Res., Manual and Guides, 1994, 29, p. 170.

[36] van Boeckel W.H.M., Ability of Phaeocystis sp. to grow on organic phosphates; direct measurements and prediction with the use of an inhibition constant, J. Plankton Res. 13 (1991) 959-970.

[37] Vaulot D., Birrien J.L., Marie D., Casotti R., Veldhuis M.J.W., Kraay G.W., Chretiennot-Dinet M.J., Morphology, ploidy, pigment composition and genome size of cultured strains of Phaeocystis (Prymnesiophyceae), J. Phycol. 30 (1994) 1022-1035.

[38] Veldhuis M.J.W., Colijn F., Venekamp L.A.H., The spring bloom of Phaeocystis pouchetii (Haptophyceae) in Dutch coastal waters, Neth. J. Sea Res. 20 (1986) 37-48.

[39] Verity P.G., Villareal T.A., Smayda T.J., Ecological investigations of blooms of colonial Phaeocystis pouchetii-I. Abundance, biochemical composition, and metabolic rates, J. Plankton Res. 10 (1988) 219-248.

[40] Wassmann P., Veret M., Mitchell B.G., Rey F., Mass sedimentation of Phaeocystis pouchetii in the Barents Sea, Mar. Ecol. Prog. Ser. 66 (1990) 183-195.

[41] Wyrtkii K., Oceanographic Atlas of the International Indian Ocean Expedition, National Science Foundation, Washington, DC, 1970, $531 \mathrm{p}$. 